\title{
INVISIBLE LINES, INVISIBLE LIVES; EDUCATION OF AFGHAN MIGRANT CHILDREN AND THEIR FUTURE WITHIN IRAN'S BORDER
}

\author{
Author: \\ Mozhdeh Taherizadeh \\ University of Debrecen (Hungary) \\ E-mail address of the author: \\ taherizadeh.mozhdeh@arts.unideb.hu
}

Lectors:

\author{
Gábor Biczó (Prof., Habil., Ph.D.)
}

University of Debrecen (Hungary)

Taherizadeh, Mozhdeh (2021). Invisible Lines, Invisible Lives; Education of Afghan Migrant Children and Their Future within Iran's Border. Különleges Bánásmód, 7. (1). 91-108. DOI 10.18458/KB.2021.1.91

\begin{abstract}
During the Soviet Union occupation of Afghanistan, the Taliban insurgency within this country's borders, and a subsequent war with the USA, people inhabiting this land were forced to leave their country to cross the neighbouring borders with Islamic Republic of Iran. Exploring their right place in Iran's society resulted in residency of approximately 3.000 .000 of them, which has yielded both constructive and at the same time disturbing economic and educational experiences for both nations. Cultural similarities and deviations, in some cases mutual language, and common religion have been presented as the underlying reasons for integration opportunities and also challenges. This study explains how the trends for delivering education to Afghans in Iran have fluctuated so far, yet been remarkably more efficient than their departure point. The educational future of the second, third, and even fourth generation of Afghans in Iran has become a big question with regard to economic status and political relations of the two countries. What this study manifests is the need to recognize and fill the gaps in the education of Afghans. This goal will be achieved through a review of human rights opposing geographical determinism, illiteracy, and mistaking prejudice and excessive behaviours in the host country.
\end{abstract}

Keywords: Afghans in Iran, ethnic refugees, identity conflict, future generations, school integration Discipline: sociology

\footnotetext{
Absztrakt

LÁTHATATLAN VONALAK, LÁTHATATLAN ÉLETEK; AZ AFGÁN MIGRÁNS GYEREKEK OKTATÁSA ÉS JÖVŐJE AZ IRÁNI HATÁROKON BELÜL

A Szovjetunió Afganisztán-megszállása, az ország határain belüli tálib felkelés és az azt követő USA-val folytatott háború eredményeként az e földön lakó emberek kénytelenek voltak elhagyni országukat, átlépve az Iráni Iszlám Köztársasággal szomszédos határokat. Mindez az iráni társadalomban körülbelül 3.000.000
} 
ember tartózkodását eredményezte ami konstruktív, ugyanakkor zavaró gazdasági és oktatási tapasztalatokat hozott mindkét nemzet számára. A kulturális hasonlóságok és eltérések, egyes esetekben a kölcsönös nyelv és a közös vallás az integrációs lehetőségek és kihívások mögöttes okaként lettek prezentálva. Jelen tanulmány elmagyarázza, hogy hogyan ingadoztak eddig az iráni afgánok oktatási tendenciái, mégis kiemelkedően hatékonyabbak voltak a kiindulási pontjuknál. Az iráni afgánok második, harmadik sôt negyedik generációjának oktatási jövője nagy kérdéssé vált a két ország gazdasági helyzete és politikai kapcsolatai tekintetében. A tanulmány célja annak bemutatása, hogy fel kell ismerni és ki kell egészíteni az afgán oktatás hiányosságait. A cél elérése a földrajzi determinizmussal szemben álló emberi jogok, az írástudatlanság, az előitéletek és a túlzó viselkedések a fogadó országon belüli áttekintésének összetévesztésén keresztül fog megtörténni.

Kulcsszavak: afgánok Iránban, etnikai menekültek, identitáskonfliktusok, jövő generációk, iskolai integráció

Diszciplína: szociológia

\section{Historical background}

The choice of living space has not always seemed available, partly due to administrative regulations and partly due to lack of insight on behalf of the individual. The latter case had been one of the very first aspects of the primary human decision-making faculty. It means that the right to property ownership at times had blocked the view toward the choice of examining other available places. Nonetheless, the nature of the sense of safety justifies permanent settlement with an exclusive full right of access.

This study portrays how the younger generation of people labeled as Afghan immigrants/refugees receive their share of basic human needs, specifically education and scientific progress in the Islamic Republic of Iran, and what the obstacles are on their journey of life, crossing geographical borders.

A large number of Afghans were forced to cross the borders surrounding their country (see Graph 1) as a result of England and the Soviet Union's geopolitical interest in the territory labeled as Afghanistan, mostly in 1979. As expected from all types of power plays, interests of the ordinary people and children are ignored, education specifically, in favour of ethnic, racial, cultural, and ideological frameworks (Mossalanejad, 2009, p. 170). The generally poor literacy status of the Afghans inside their country not only experienced no positive growth as a result of the Soviet Union's occupancy, but it also exacerbated. The reason was a following domestic rise of the extremist Taliban force in 1996 and the U.S. attack in 2001. The territory had enjoyed only a not so long independent history from after the Second World War (Yasna, 2019, p. 183). What is obvious is that during all these conflicts overruling power, no resources were left for the management of the basic needs of the people. Negligence towards education started along with the new system and governance. As Pashtun became the official language, school textbooks became Pashtun without considering the high rate of dropouts because of the replacement with a language that the majority didn't know and couldn't understand and even there weren't enough teachers to teach it (Yasna, 2019, p. 201). After the 1990s, with the 
doors open at Iranian borders, the opportunity for seeking security across the borders blocked any policy consideration for handling the issue within that nation. The international human right supports required the need for health and education of these people to be answered in the host country which again created the motivation for immigration rather than a constructive solution inside Afghanistan, let alone the development of literacy. Consequently, as time passed, generations came after generation without any long-term solution possibilities for recovering the roots of a group of people with a distinctive branch of culture and tradition. Most attention has been focused on facilitating integration by not placing the newcomers in sanction or shelter, but by permitting them to choose their place of residence, on behalf of various sources such as the International Organization for Migration (IOM) and the United Nations High Commissioner for Refugees (UNHCR). Efforts are made in form of organizing bilateral and tripartite correspondence with close and far away states remarkably Australia and Germany, along with several NGOs and civil society organizations (Marchand, 2014, p. 245).

Cultural, religious, and historical closeness, as well as a common language among the Iranian and the majority of Afghan migrants, have been the basis for humanitarian approaches toward the betterment of a group of people stuck in an unintentional unpleasant situation. Case studies in major Afghan settlements located in larger cities of Iran show that Afghans prefer Iran despite all integration issues and generally do not intend to join repatriation programs of any kind (Net5, Net3). Statistics will be presented regarding the voluntary repatriation percentage as well as the tendency not to return to Afghanistan. Despite this fact, the future anticipated for Afghans in Iran, even the documented individuals, is not permanent by any means, let alone granting Iranian citizenship even after more than 20 years of stay or being born in Iran (Squire, 2000, p. 7).

Better access to education is a major pull factor in Iran, so integration and repatriation strategies have been put forth with different intentions targeting the reservation of the Afghan traditional cultural authenticity to encourage these peoples' voluntary return (as Afghanistan has been declared safe in this regard). For example among the first steps taken to accelerate Afghan return to their country, is included a ban on the education of Afghan children after several years of equal right of accessing schools as the Iranian kids; such moves have been taken along with more serious measures like forced deportation of undocumented Afghans, which in itself denotes the potency of educational motivations on migrant groups. Many parallel programs through UNHCR and organizations with similar intentions assisted 918,263 Afghans involuntarily return home (Azizi, Hosseini, and Basavaraju, 2017, p. 78) or helped their smoother integration if decided upon permanent stay. In this study, the goal is to present a discussion advocating Afghans' right to either stay in Iran or return to Afghanistan as humans, regardless of either choice, with the help of schooling.

In this study, the author tries to use mostly the findings and understandings of researchers who are Afghan or Muslim, Middle Eastern, or those who speak the same languages as Afghans to examine their culture, customs, and socio-cultural codes. The foreigner view may leave some hard-to-reach concealed aspects out of the consideration zone, while those might (and most probably will) seriously contribute to tactful decision making.

The other part of this paper's aim will be practical by again keeping in mind that the steps taken so far have mainly focused on recurrent issues such as facilitating integration in both social and educational settings. These include giving Afghan children equal chances and quality of education as the Iranian kids, providing decent 
documents and proper identity recognition facilities, and exploring the best approaches to healthier repatriation whether in a voluntary or forced manner. Nonetheless, it is intended in this article to manifest the need for recognition of the significance of humanity on the individual scale on an international level and the necessity of including lessons in this regard while designing school books and regulating policies for offering opportunities for education to the younger generation that is going to be the future inhabitants of society. In the case of migrants, specifically, Afghan people in Iran where they share similar cultural, historical, social traditions and the ground is suitable for a level of integration that is constructive for both nations, schooling must orbit around the fact that human being is originally free and supposed to help fellows. Based on Milton Gordon's categorization, it can be said that the extent of assimilation practiced and experienced by Afghans in Iran falls in various categories, given the fact that Gordon's examination of Western communities will not necessarily match the path Eastern ones go through during their assimilation process (1964). A more detailed introduction on Afghan ethnicities in Iran will be given in the Ethnicities section of this paper.

Also, generally, it can be expected that Afghan ethnicities respond differently to the Iranian environment; based on being Hazara, Pashtun, Tajik, Baluch, ... (where on the spectrum of background closeness to the Iranian society), each group will be absorbed differently and to a different extent. For example, since the Pashtun share similar facial complexion, if their second and third generation can acquire language skills and articulate Persian accent, their level of Behaviour receptional assimilation in educational settings and chances for Civic assimilation are higher, followed by a more positive outlook toward their future in Iranian society, while a Hazara cannot be hopeful in that respect because, despite even the closest articulation of the language, their facial features will be distinguishing. It should be noted that such a hypothesis can take place in real life if laws in effect for the occupation of Afghans, and the Pashtun prejudice against acculturation, in general, were in favour of the potential.

With the retrospective view toward the shared history of the two nations, the assimilation state of newer generations of Afghans in Iran's society by Gordonian words may be expressed in this way: Acculturation and identity formation can be seen at play with the slightest effort while the first generation preserves more of its communication codes which keeps them inside the circle of compatriots. Moreover, due to a similar religion in the host society, the first and later generations show similar religious tendencies, which along with the previous statement, causes smoother Structural assimilation for the second and the later generations. Because of schooling of second and later generation of Afghans as a means of socialization of migrants with the Iranians, these people are less attached to their origin in comparison with the first generation arriving to the country as adults with the experience of living in Afghanistan's society.

\section{Afghan cultural background and lifestyle}

Ancient Persia consisted of present Iran, present Afghanistan, Tajikistan, Turkmenistan, and several other countries that now form the complex neighbourhood including present Iran and Afghanistan. In the realm of human sciences, the region is known for the Culture of Persia which consisted of various elements such as language, religion, culture, mythology, and holidays or events that are common among all the involved countries mentioned above (Yasna, 2019, p. 182). Harat city of the present day in Afghanistan has formerly been a province of Iran up to more than 150 years ago (1856) and at those times called Khorasan. The present bordering province in the North East of 
Iran adjacent to present Afghanistan has the same name (Yasna, 2019, p. 195). Even before the time of separation, the leaders were from among Pashtun people who are one of the ethnicities constructing the Afghan community along with the Tajik, Hazara, Baluch, and a few others.

As the results of a series of questioners show, the conflict between the two most intensely rival Afghanistan ethnicities, Pashtun and Hazara, is so broad that a suffering migrant youth from the latter group would feel happy if it is known that the Pashtun are equally suffering the migration challenges, because the experience counts as the reprisal for all the torture the Hazara ethnicity had gone through back in their common country; as the researcher reports, "the voice coming out of the 25 years old Hazara youth's throat, trembles with a sense of revenge against the oppression resulting from ethnocentrism" (Yahyaei and Kia, p. 155). Even literature-wise, "the ideal personality type in Afghanistan is the warrior-poet: brave in battle, eloquent at the village council" (Hatch, 2002, p. 979).

Science and knowledge had nothing to do with the formation of this hierarchy as the Pashtun have not been any more literate than the Hazara; Afghanistan is known for illiteracy, the origin of terrorism and its expansion, and the source of tobacco production (Mossalanejad, 2009, p. 171). By 2020, a forty five-fold increase in the production of narcotic products has been reported. In the traditional social sphere, hardly can anything equal the passion for poetry; even women literary figures have at times established a name for themselves through literary practices with intentions other than mere prosing (Hatch, 2002, p. 979). On the other hand, in 1998, the illiteracy rate in this country was estimated as high as 90 per cent (Yahyaei, Kia, p. 142).

Regarding the scope of this paper, purposeful displacement of household and settlements is not a novel trend to be introduced to Afghan history in the last few decades; it has been a habitual strategy due to reasons such as natural disasters for which from centuries ago the Islamic Republic of ran have been a decent alternative (Marchand, 2014, p. 29). Combined with the profound significance of family institution among the Afghans, group migration has become a common feature observed among the members of Afghan settlements. The high number of kids is a consequent of customs and cultural codes that can save parents' dignity and will not be abandoned for almost any particular reason. This factor leads to another main feature of the Afghan community, which is the prevalence of kids participating in the labour market (Net5). This outcome is representative of a certain fact regarding the Afghan lifestyle; engagement in low paid manual work complies with the environmental and social aspects of lifestyle in Afghanistan. A technologically underdeveloped state with people mainly working on fields on mountainous lands, where having the equipment to bring cooking fire in a separate interior space called the kitchen, and at times access to drinking water and latrine is a privilege.

\section{Ethnicities}

Despite Afghanistan's poor economy, its people have a "profound belief in the humanitarian, egalitarian teachings of Islam" and at the same time rarely boast about their purity of deeds, as correspondingly find downright fault with fanaticism (Hatch, 2002, p. 980). Obviously, the existence of an ethic doctrine in a society's code does not guarantee the practice, and Afghans are a bold example of representing the foible; ethnic rivalry especially between Pashtun and Tajik versus Hazara people, and the rebellion of a fanatic group such as Taliban against one's own nation is a realization of the unfortunate truth.

Ethnically, Afghans fall into several categories based on oriental studies. The majority of the 
population are the Pashtun who speak the language also called Pashtun. In Iran, the second most number of Afghans are Hazara (although not more than the Persian speaking Tajik in Afghanistan) who speak Dari, a slightly different version of the modern Persian and a very important reason for the cultural ties between these people and the Iranian as former citizens of the same country (Yahyaei, Kia 141).

A very bold point of divergence between the two main Afghan ethnicities lies within their religious, traditional, and geographical background among all. Other ethnicities are more or less either recognized with the Pashtun or the Hazara since the more geographically a settlement close to Iran, that ethnicity accords with the Hazara and the Iranian culture, like the Baluch, as in the most Eastern provinces of Iran, people are the Iranian Baluch. The opposite is true about the ethnicities residing in the centre or East of Afghanistan, further away from Iran, where the people feel less attached to the Persian culture or even to the other Afghan ethnicities. Such a physical and traditional remoteness is exacerbated by the fact that the majority of Pashtun and Tajik are Sunni Muslims but the Hazara are Shieh. Another contributing factor can be the stronger sense of nationalism among the Pashtuns as a self-identification source rather than their religion (Jawad, 1992). These have been (among others probably) the sources of conflict inside this country's borders, since the former groups have always exhibited prejudice and superiority over the latter, as it has been the case in their ruling history as well (most Afghan leaders are from among the Pashtun and the Tajik).

\section{Education tradition}

Parallel to the traditional and elementary customs prevailing in Afghanistan especially during the turbulences of the last forty years, evolution of the education in its modern form has experienced major ups and downs, still not maturing even as developing countries with medium level education. Back in the history of education in Afghanistan, despite the public interest in literacy, the strongly religious customs had limited education to small classes taught by religious preachers focusing on primary literacy and Islamic knowledge. Obviously, the dominant patriarchy weaved into all levels of social institutions would not allow for girls to participate. Historically even some Afghan leaders were dethroned for such Takfir (acts harshly against Islamic doctrines). Many regarded these changes with disapproval and finally, in 1929, expressed their displeasure by expelling King Amanullah (1919-29) (Hatch, 2002, p. 981).

Closer to the more modern governmental system prior to the Soviet occupation and the consequent wars, the development of the educational system was experiencing a flourishing trend in a way that both boys and girls were engaged in not only primary but secondary and tertiary education, building on foreign models of ruling and authorizing the nation. In the case of this improvement also the lack of comprehensive policies in a way to benefit the whole country was present since as Hatch writes, all achievement was limited to the capital regions where the elite were settled, leaving all other regions and their people's share "untouched" (2002, p. 981). The evolution had been moving in such a positive direction that even some Afghan candidates were funded to study in Italian, French, and German universities. But similar to previous and also later practices, the achievements were not persisting, for with the start of the occupation and consequent conflicts, specifically with the dominance of conservative Taliban ruling, the whole education system retreated to its most primitive state, depriving girls of leaving the domestic sphere and limiting taught subjects to restricted religious ones.

During all mentioned periods the quality and distribution of the chances offered to pursuers of 
literacy and science were focally concentrated in the few main cities; the vast remaining expanse of the country did not enjoy even the basic requirements of living. Access to permanent shelter, food, drinking water, or latrine as the minimum household prerequisite was and still in settlements not so far away from towns is minimal, let alone acquiring literacy.

Moreover, literacy and education have rarely been a priority in the history of policymaking in this culture. When the more naturally warrior Pashtun reached over the throne and attempted to establish their state with Pashtun as the official language and obviously Pashtun schooling textbooks, did not prosper to manage the affairs due to a lack of decent Pashtun knowledge among the officials and an insufficient number of teachers, leaving the dream to the reality that Dari is still the official language of the nation. This very fact once more proves that how politics of power in Afghanistan has generally neglected education and schooling, and how the literacy of the people would come as a low priority. Figures reveal that an estimated 75 percent of the Afghans still in 2018 follow the general governmental strategy on the smaller scale of their families by providing the household with minimum living requirements to the cost of taking kids out of school to join the workforce; only if kids work along with the parents, the family can gain enough for one meal a day (Naseh. Potocky, Stuart, and Pezeshk, 2018, p. 9)

\section{History in Iran: Receiving}

The overall rule for allowing Afghan refugees residency in Iran can be categorized under two phases of open borders prior to 1995 and closed border after that year's tripartite along with the Afghanistan government and the United Nation's High Commissioner for Refugees (UNHCR). Generally, the most important reasons for the migration of refugees and regular migrants to Iran instead of other countries in the last decades has been stated as "war and insecurity in Afghanistan", "family's decision to move to Iran", and "religious, cultural, and linguistic similarities" Jauhiainen, Eyvazlu, and Salavati, 2020, p. 38).

Upon the 1979 invasion of Afghanistan by the Soviet Union, nearly one year before the outbreak of the war with Iraq in Iran, Afghans crossed the Iran-Afghanistan borders. They arrived mainly from Eastern provinces in Afghanistan to Khorasan Province and from its South to Sistan and Baluchestan province in Iran. This first wave of the involuntary migraters successfully crossed the borders of their host country for the mere reason of holding an Afghan identity at the borders based on sharing the same religion and was labeled as religious "refugees" or "mohajereen" in Persian, receiving "blue card" documents (Naseh et al. 2018, p. 1, Marchand, 2014, p. 30).

This policy was called prima facie which allowed Afghans as Muslim brothers to seek security within the territory of the newly established Islamic Republic of Iran. Obviously enough, many Afghans joined the front line of the holy defence against Iraq at that time. There is evidence that even a number of Afghan youth had left their country not as a result of the Soviet occupation, but with the intention of fighting for Iran as the land to which they considered themselves both culturally and religiously belonging (Net2).

This first generation of the contemporary Afghan residing in Iran, at that time enjoyed equal rights of education, healthcare, birth registration, access to court, and other social services as the Iranian citizens based on the "blue card" type document issued for them which would allow for unlimited residence. Technically a refugee status means receiving political security until the country of origin is back to safety. A common history, language, and most importantly religion was the reason that Afghans were not housed in shelters 
but resided in the center of cities and many inhibited the margins (Khairi, Rahimi, 2018, p. 148). Larger and more developed towns became the host to the majority of Afghan villagers due to the availability of more construction job vacancies as a result of a higher population. Moreover, those immigrants who did not hold any legal work permit, would secretly and unanimously participate in low paid activities easier among the crowd (Jamshidiha, Anbari, 2004, p. 50).

The second wave of mass migration from Afghanistan to Iran happened 16 years after the Soviet entanglement, in 1995 and after the victory of the mujahedeen in 1992, contrary to the expectations for peace; Afghanistan became the target of Taliban uprising from inside the nation for a dominant power (Marchand, 2014, p. 31). These people crossed the Iranian borderlines through the same provinces as before, joining the second generation of Afghans who were now born in Iran. By the next year, in 1996 Afghans in their country could hardly bear the rocketing influence of Strict Taliban ruling. However, the policies in Iran had deteriorated the extent of services offered to the Afghans; no more education or healthcare facility. This was partly due to the reason that from 1993, the Islamic Republic of Iran, along with the Afghanistan government and UNHCR agreed upon policies to facilitate Afghan repatriation with a focus on monitoring their living status in Afghanistan; the migrants arriving after 1993 were no more considered as refugees, but literally, asylum seekers since the documents they were handed, retitled them as "panahandegan" and not "mohajereen" anymore (ibid). These documents were officially temporary and remained the same regarding the permitted length of stay even after the 1998 occupation of Mazarsharif by the Taliban, if at all granted (Squire, 2000, p. 7). The number of those Afghans forcefully returned on the basis of holding no registered identity document in the years 1998-99 reached 190.000 (Hugo, Abbasi-
Shavazi, and Sadeghi, 2012, p. 268, Marchand, 2014, p. 32).

Although strategies moved toward less harsh decisions regarding the education of migrant Afghan kids, restrictions on issuing documents especially with the purpose of long-term residence continued. By early 2000, more developed digital facilities were installed at borders for gathering identification information for the aim of processing the residence permit applications which if successful (in half of the cases) would result in temporary documents in need of extension every 6 months (Squire, 2000, p. 7). Until the end of the same year, respectively 130.000 Afghans had repatriated and 80.000 were issued with temporary refugee status to stay in Iran (Azizi et al., 2017, p. 74). Following the general free choice of residence location granted to Afghans in Iran, by this time, as Squire reported, 95 percent of them had lived in urban and rural parts of the country under unsatisfactory occupation circumstances as they were not allowed to be employed in their host country, limiting their income resource alternatives to an illegal, secret, low paid jobs (2000, p. 5).

The third wave of Afghan mass migration occurred upon the 2001 USA attack on their country. With regard to the previously in practice closed borders policy on the side of Iran, migrants following this phase were either illegal, or along with all the previously residences already in Iran, granted short residence permits that had to be renewed every three months up to four times (Abbasi-Shavazi, Glazebrook, Jamshidiha, Mahmoudian, and Sadeghi, 2008, p. 6). Despite the fact that this country was struggling with another ongoing war, the next year, another program was launched mainly left to UNHCR for implementation, to aid the voluntary return of Afghans not only from Iran, also from Pakistan (Lumpp, Shimozawa, and Stromberg, 2004, p. 149).

The number of arriving population during each phase must be obtained considering the number of 
repatriated from among the migrants of the previous phase which is not a straightforward calculation. The reason is that waves of migration from Afghanistan to Iran did not happen at once; Afghans would and still do cross the Iranian borders on a daily basis, with regard to the fact that some also return every day. For instance, regarding the second wave, according to UNHCR based on the report by the US Committee for Refugees, at that time some 1.4 million Afghans "lived" in Iran (Net8). The terminology used in the case of Afghan migrants to a country with shared borders is explanatory. It means that the figures are subject to constant yearly, monthly, and even daily changes. Also, the only resource for publishing the consensus is the government of Iran which is released every five years. It is obvious that with the maximum yearly change of identification document policies and types (in some cases every three months), many will remain unreached both in terms of their arrival or departure and in terms of the overall fluctuating number.

With an account of the fact that Afghanistan was not announced safe until after 2014, it is obvious that a great number lost their legal status, and many did not bother applying for it due to troublesome and costly practices. The ineffectuality of that decision for legalizing migrants' state or facilitating monitoring the foreigner population is in part a result of the mere fact that even at present, after 7 more years, except for four main capital cities, the rest of this country is still not inhabitable neither in terms of security nor basic living infrastructure. The fact is notable since the bulk of the Afghans have to reside in the improper regions upon return.

Iran is the first host country in the world to embrace the highest number of refugees in its urban parts; 951,142 documented Afghan refugees live in this country, and around $97 \%$ of them live in urban and semi-urban areas (European Commission, 2021, Naseh et al., 2018, p. 3). They are occupied with non-governmental hard manual labour, receive low wages, and consequently enjoy low social status because better jobs are initially for the Iranian identity, and even if they own the capital to run their own business, they are not allowed to (Abbasi-Shavazi et al. 2008. p. 27). As Jauhiainen et al. report, in the last five years prior to 2020, almost no Afghan refugees came to Iran compared to the fourth generation who are all born in this country (2020, p. 35).

Among the present Afghan residents in Iran, there is the second generation a great number of whom were born there. The third generation born to the second generation are all born in Iran and the fourth generation already lives in this country (Jauhiainen et al., 2020, p. 37). Issuing Iranian citizenship is not possible for any generation of Afghans except for those who are born to Iranian mothers, and those who hold specific talents (Jauhiainen et al., 2020, p. 32). However, the obvious matter of fact is that overall Iran has put the best possible on the tray, considering her own state as just developing, and the number of refugees is disproportionate compared to any other country in the world.

\section{Education in Iran}

Ministry of Education and Training (MET) is the authoritative body for schooling at primary, guidance, and secondary levels. All these levels are to be passed prior to university education. All schooling is announced to be free but in practice, parents are asked and required to pay amounts for registering their children or to be able to obtain their end of the year reports. According to Squire in 2000, only five years of primary school are mandatory and there is a serious need for parental assistance in more than two hours long daily homework (2000, p. 10). Regarding the education of Afghan refugee children, Iran is a signatory to the 1951 Convention relating to the Status of Refugees (in 1975). The 1951 Convention, Article 22 , states that “...States -shall accord to refugees 
the same treatment as is accorded to- nationals with respect to elementary education" (Squire, 2000 , p. 7). Based on a study in 1992, BAFIA (the bureau for aliens and foreign immigrant affairs) reported that nearly 654,000 of the Afghan refugees in Iran had access to educational services at all levels, and according to MET-UNICEF report in 1999, more than ninety thousand (4\%) students were participating in primary school classes (Squire, 2000, p. 10). Although, "of those who returned from Iran with UNHCR's help during the year 2002, 70 percent said they had no education" (Net4). Previously in 2000 Squire had identified that many families need children to work in order to contribute to the family income, in view of increasing restrictions on Afghan's employment, so they have to take children out of school (2000, p. 25).

As early as 1983 , with the first wave of mass migration of Afghans to bordering provinces of Iran specifically Mashhad, the very first selfregulated Afghan schools with tacit notice of MET and BAFIA in the main settlements such as Golshabr to serve the group of students who had been kept out of school as a result of a ban on enrolling undocumented Afghan children in staterun schools (Hugo et al., 2012, p. 268). Although there is evidence that even until a decade later and up to 1996, Afghan undocumented children were at the mercy of school principals, so able to attend government-run schools (Squire, 2000, p. 8). Implications of Iranians' hospitality toward Afghans which contributed to their easier integration are multitudinous. Still, the fact prevails that the self-regulated schools are run with minimum facilities and materials. They hardly try to keep up with the Iranian schedule and education system with no content available for Afghan students relevant to neither Pashtun language nor history and geography of Afghanistan; all Afghan kids are offered to share with their Iranian peers as members of the same society, is some basic information in the $5^{\text {th }}$ grade on the four main cities (Kabul the capital, Herat, Kandahar, and Mazarsharif ), agriculture as the main occupation, names of some lakes, mountains, and rivers, and their economy orbiting around sheep rearing and textile production (Squire, 2000, p. 10).

Restrictions put on school registration policies grew tighter in 1998-9 and limited allowance for enrolment of Afghan migrant children in schools out of their identity registration region. Moreover, in larger cities with larger populations of Afghans, they were restricted only to schools located in settlements designated for Afghans (Squire, 2000, p. 8). However, the figures for Afghan children attending upper levels of guidance and secondary school saw an increase of 500 more students between 1994 and 1999, creating a total of 35.000 in a constant manner of increase, with a higher dropout rate for boys which demonstrates that perhaps the rise in numbers was mostly due to more engagement of girls. Obviously, these numbers do not count for all Afghan kids in Iran (estimated by that time to be 500.000 aged 6-15), but the percentage in total was as low as $6 \%$ and $11 \%$ for graduates from high (Secondary) school and receivers of vocational qualification; figures for kids enrolled in governmental primary schools were the highest, representing more than 100.000 (Squire, 2020, p. 5 and 12).

Children who were not in formal schools, either attend the schools run by Iran's government with Iranian staff and the help of UNHCR in the refugee camps located at Eastern provinces, or LMO classes offered at five primary levels of primary school (respectively 3000 and 18000 students by 2000) (Squire, 2000, p. 13). The year 2000 was a turning point for Afghan schools because prior to the beginning of the school year, they received a letter ordering not to open for the coming year; Once again state strategies took over the priority of schooling and accelerating repatriation targeted the education of children. 
With the unfortunate policy, during the next years, the informal system of Afghan schools witnessed a growth in the number of unofficial, unregistered schools in form of old buildings and houses serving Afghan kids covertly that if discovered, would be shut down (Net6).

In 2015, the current supreme leader of the Islamic Republic of Iran officially announced an order emphasizing the obligation of enrolment of all Afghan kids, be legally or illegally resident in the country in public state-run-schools. The next year, 48.000 students holding status quo experienced school registration and the numbers reached 400.000 by 2018 (Net8). With this major modification, however, the tradition of informal schooling did not vanish, and along with exacerbating the financial status of Afghans in Iran's suffering economy, Civil activists together with child rights experts in 2012 estimated the number of out of school Afghan children in Iran at 400,000 or 500,000 as of the German broadcasting organization Deutsche Welle in 2017 published. This news agency focusing on the migrant Afghans in Iran also adds that during recent years, figures for out-of-school Afghan kids rose to almost 1 million, but those that welcome the chance of attending public schools can receive their certificates from Afghan consulates or embassy (Net6).

Overall, narratives convey the truth that in terms of migrant education in Iran, neither numbers nor promises are to be trusted. As results of studies conducted in the 2000s revealed, the results drawn out of studies orbiting the education of Afghan kids in Iran have been paradoxical, as the most recent ones still come to similar ends. Decisions to terminate studies are mainly based on financial difficulties and lack of prerequisite ID and residential documents. Comparably, the good attitudes of Iranian teachers and classmates are stated as pull factors and motivations for acquiring higher qualifications in an attempt to gain a more recognized social status (Abbasi-Shavazi et al., 2008, p. 20). As UNHCR statistics for 2019 demonstrate, 480.000 Afghan children are receiving education through various policies in Iran, 130.000 of whom are undocumented and 60.000 newly enrolled in that school year (Net1).

Immigrant children in Iran are offered education by programs offered through governmental, international, private, charity-based, and many other different means. Apart from UNESCO, UNHCR, BAFIA, MET, and the two Islamic republics of Iran and Afghanistan (the assistance of which is required more than its present extent, the center for providing cultural and educational support for refugee Afghan children in Iran, Khaneye Koodakane Afghanistan or Afghanistan Children's Home and KCIS are actively participating in activities to advocate and implement a more qualified schooling experience for Afghan children, side by side of many national and international NGOs. Khaneye Koodakane Afghanistan has started its activity in the Fall of 2004 by designing and publishing extracurricular material such as holiday workbooks, magazines, cultural orientation and art workshops for students and trainings for teachers, etc. and has also published and distributed the social sciences school subject textbook "Bazgasht" ("Return") among non-state independent Afghan school in Iran. This organization's ultimate goal is to help raise a future generation of citizens who can be anti-racism advocates of peaceful humanitarian policies. Keep Children In School, an organization based in CA, United States, and its operational arm, AYDM (Anjoman e Yaran e Danesh va Mehr) in Iran, carefully identifies and selects children in need, including Afghans, who show academic promise. KCIS is then responsible for matching these children with sponsors, who become their guardian angels supporting them through their educational journey. 


\section{Argument}

There is a contradiction concerning the integration of Afghans in Iran; the conflict that the second and third generations want to be considered as rightful immigrants but the environment does not let them deny that they are refugees in Iran. Despite the frequency of opportunities offered to these guests for providing them with the requirements of a decent life such as education, health care, etc., a lack of attention paid to their socio-psychological state has always prevailed. In this manner, these people have never been able to envision a future in Iran which has left a sense of uncertainty present in their everyday lives. A weak attendance on behalf of the suffering Afghan authority regarding their own people has been a major factor. Also, the deteriorating economy in Iran as a country engaged in international disputes has added to the limitation of the immigrant labour force absorbance capacity; since Afghan immigrants mostly arrive from a nonofficial employment background, they had the chance to be occupied in the majority of vacancies on the job market.

Inside their country, too, those Afghans willing to fight, such as the prejudiced Pashtun would engage in defending, and anyone not interested would move to Iran into a more convenient culture. Now what remains as the technical void is the mission of the Afghan who is dragged out of its original place to somewhere they did not have a say in choosing, but humanitarian-wise speaking, the same trend should be available, at least through schooling possibilities; this means that education about both Afghan and Persian culture should be offered, only with no bias and through fully optional results, so that a knowledge of individual will as the most important driving factor in social conduct is internalized.

The paradox is mostly present in the situation of the students (the second and third generation): complying with the requirements of being an immigrant but undeniable refugee identity as a result of incapability for picturing the possibilities for return to the homeland. The contents that Afghan children receive in Iranian schools are scientifically decent to convey the general knowledge a student shall receive in the common fields of biology, mathematics, literature, geography, and even ethnic history (only with the intention of facilitating integration). But the gap to be addressed rests on the body of social education targeting an afflicted group. The permits with rights equal to Iranian citizens resulted in the resumption of the customary Afghan life style in a host country with a modernized lifestyle despite the traditional cultural similarities. Hatch perfectly observes that how potential Afghan culture is to preserve values, and how its people strongly play the roles indoctrinated in them, although challenged in a diverse environment in Iran (2002, p. 985). Outcomes are outbursts in the form of experiencing racism, integration difficulty in school, society, and workplace, a problematic system of household management in a larger incompatible economy, and finally an unreachable prosperous future. All these factors then enter an unending cycle where each becomes the cause to the other, creating an entanglement that could be prevented by well-timed education. Now after four decades past the co-habitation of Afghans and the Iranian society, the second generation of Afghans, who arrived as children or were born in Iran, could be the most valuable resource for implementation of a positive integration knowledge. If In a consideration of long-term residence of these immigrants had penetrated school material design for at last the second generation of Afghans in Iran, their status and also their issue of integration would have been handled with mush less difficulty and much more tolerance.

With the current laws in practice in Iran as the agreement among all responsive partners, even they can be considered asylum seekers who have to 
struggle to prove themselves as immigrants. The reality is that they are no more refugees and their status has changed to asylum seekers whose sense of being a human with rights does not let them see themselves other than immigrants at the lowest. In some cases, they would prefer Iranian citizenship based on the sense of otherness many of them have experienced while on trips back to Afghanistan. Obviously one of the quintessential means for transmission of socio-cultural doctrines is schooling which could be the tool for the implementation of logical decision making and human rights crisis management.

To the second generation Afghan migrants in Iran, it may seem too late to initiate long term strategies, now that they are in need of a source of income in Iran, are in intense competition with the Iranian workforce, and see no way back to Afghanistan due to war or lack of any background to return to. This is why the gap is widening due to a lack of consideration regarding international, comprehensive solutions that target the whole human (i.e. all generations) arena case of involuntarily displaced people. Moreover, any step taken in this regard needs to be up to date since as previous studies show, each generation exhibits different capacities and expectations, as the first generation of Afghans who had gone through more physical and mental hardship from multiple wars and vagrancy, faces integration barrios with a higher tolerance but the next generation that are born in Iran, have socialized with the Iranian culture of expectations (Khairi, Rahimi, 2018, p. 148). Consequently, these newer generations may not be able to comprehend the downsides of being a migrant from another land, let alone to a destination in which they find a common language, religion, and countless customs. Representation of environmental determinism questions in their own lives may outpour their tolerance; the significance of their worldview lies in their existence as humans and any activity directed toward supporting human rights must be capable of handling this truth.

Humanitarian activity means helping humans live a peaceful life in safety and confidence. Some third parties have opened the war on Afghans without their own will, they had to escape, and now who has the right to send or direct them where they do not want? There is also the question of the state of a country that is not capable of running a life suitable for humans within its borders; preconditions for a piece of land to be labeled as a country do not necessarily mention the quality of life experienced and propagandised in it. The reason that ties humans to a certain point on land within a defined border is the main question occupying the mind of every Afghan refugee (even the labels that are attached to their identity documents from time to time change so frequently, downgrading them to subjects rather than humans more than before).

During the first phase of mass migration to Iran, as registered Afghans holding "blue cards", they were all able to attend Iranian state schools to receive the scientific education available to every other student in any school anywhere in the world. After several decades, still, the gap referred to is that of receiving schooling in the first place, with no space opened for social education tailored for forcefully displaced humans. Training programs executed by UNHCR look forward to another displacement by preparing Afghan youth for potentially available vacancies in the Afghanistan job market. However, these are still hypotheses to be put into practice which is pending for the field not ready and the political security not provided enough for these programs to be initiated. Students are examined as an asset but provisions have not been enough to prepare the infrastructure in Afghanistan to utilize this potential. Forcing teachers and students back over the border is useless when there is no school, textbook, stationaries, and a domain that calls for educated 
people to take part in the reconstruction of, let alone creating hope of a life in a body of humans who will not have a share of equal human life experience.

The role of individual will and logic cannot be neglected either. An individual entering a different phase of life in which even the very basic prerequisites are unstably distributed is expected to ensure that the ground is proper enough for other peers or mates to join (if she/he was supposed to recommend). Bringing another individual to life through reproduction counts as recommending life on Earth as one has experienced to someone else. In the midst of two wars (with The Soviet Union and war with Iraq), Afghan refugees in Iran were transferred from turbulence to promised stability. Massive fertility rate based on traditional family structure with generally five kids along with insufficient education infrastructure and the provision to send kids to school, resulted in the formation of a large body of labour force for which there hardly were vacancies. Iran's population growth policies exacerbated the way Iranians and refugees were supposed to benefit from available resources; the government of Iran has been responsible for its own people, so Afghans were to take control of their circumstances in the first place. As even general education was not accessible for Afghan migrants before they came to Iran, there cannot be any expectation of crisis management or social science knowledge offered to them as school kids. Obviously enough, the second generation Afghan migrants were born to the same situation as their parents, but with global consensus over handing out help to these humans, the missing self-aid integration strategies concentrated on constructing a fruitful future could be juxtaposed to the existing curricula offered to migrant students in Iran to rescue the third and fourth generations, to increase chances of wellreceived migrant status, to create a better future for the previous generation in the host country, and to be of help to the host country by boosting economy and science.

Some Iranian advocates of child rights twittered "Mehr Hashtag" almost a month before the 2017 school year with the aim of propagating the need for education of young Afghan migrants. "The move made the education minister promise on his Twitter page that this year, no Afghan child would be deprived of an education" (Net6). The support from the host country comes in various forms; that sense of sympathy arisen from among Iranians whose family members experienced migration and asylum in other countries, or those who find themselves in the same situation. Afghan migration could be seen as an opportunity to expand the horizons of Iranian / Persian logic on an international level, by becoming the pioneer in the science of migrant integration and migrant future progression. Receiving massive numbers of culturally close migrants could be the arena for security, economy, and international relations progression, as well as bestowing a huge number of free humans the chance to dwell lands vaster than only one country.

\section{Humanitarian gaps}

To the post-modern scientific critic, it is no more a secret that the motivation behind limiting individual access to lifestyle choice is for the sake of development and it is not the case in a paradoxical manner. The explanation would be that as technological achievement could bring states superiority over other powers, the commonwealth had to be utilized to make the goals happen; there has to be a border with which the authority would be recognized, as a prerequisite for entering the competition for more power, therefore the common people's individuality has to be sacrificed for the individuality of state. Not to be excluded the fact that none of these steps are taken with the intention of the common people themselves. The 
cycle of development starts where the state seeks superiority, then it requires the citizens to gain it, then the citizens reach out for it inside and outside the borders but the state limits their access, so the state's development has to remain pending, and the cycle goes on. Consequently, amenities are offered to keep the mouths closed.

What Afghans feel about Iran is important because if a suggestion is supposed to be made for them to stay or to leave, it is their own opinion that matters. Otherwise, making them stay or leave by force is a repetition of the original starting point. This is why a logical exercise of the individual will is vital. If they were asked from the beginning about what they wanted, even now they could be wherever they wanted. If their kids are not educated, they will grow up as an undecided and scattered flock who would regenerate more similar people which results in worse circumstances both for them and for Iran, leading to more hostility. Education in this context means knowledge of life, the role of the individual in society and in one's own and peers' future. Otherwise, teaching mathematics and biology does not necessarily satisfy all the problems in the community of humans.

Speaking in the broad sense is not called humanitarian. If it is supposed to benefit the human, the entity, the creature as it is worthy of a life and health and peace on an individual scale (i.e. life of each and every single human member matters), then a general attitude looking for solutions that benefit society (either the host, the origin, or the moving flock) does not count as useful. What it means is that each and every step must be in line with the individual needs of the human member of this homeless group, not what is presumed to be of good to all three parties involved. A decent illustration of the notion goes like if a decision is agreed upon because it generally is of good to the origin, the host, and the stateless people at once, it is not correct; every decision under the name of humanitarian support must be targeted at the human individual, not its origin or host country.

Moreover, immigration (depletion of the country) results in more immigration and more alienation. It means that when a country is becoming empty of people because of bad conditions, more and more people want to escape the space temporarily and wait for the circumstances to get better to return. It's not only Afghanistan; every country's people as the majority who have no authority to make change to their own life or their country (because the power is on the top deciding for everyone and it is true about the whole world), decide to leave and hope for the others to correct the life there but as many decide the same and the remaining cannot do anything, the troubled countries become less and less crowded by hopeful people capable of making contributions, and that nation will not develop again. Children are the generation who did not choose at all and suffer the most. A Double involuntary state explains their situation well, meaning that first of all they did not choose the war, and also they did not choose to be in this world during a war or refugee life. The double involuntary state challenges also consist of the identity impediment, leading to a challenge within a challenge. This exacerbation of the problem must be taken into consideration especially in the case of those of the newer generation who were suffering a lack of identity in Iran and are now back to Afghanistan as kids and even do not belong here, and are constantly on the move as IDPs in Afghanistan too.

\section{Conclusion: educational requirements}

Everywhere in the world, war destroys and hard work and tolerance are required for a rebirth of potentials. Iran became the host for a war-fearing flock shortly before it experienced a war. The 
culture of immigration in its modern sense is expected to evolve no longer than a human's average life span. With nearly 40 years past the Iran-Iraq war and the first wave of Afghan immigration to Iran, issues of development after the establishment of a new regime made the integration of Afghan immigrants no easier. While it is expected that Iran as a nation suffering from war be able to put its experiences into practice to help the Afghans, issues (mostly economic) brought about by them have not helped the progress of their integration. Occupying the market and replacing the native work labour has been one of the main causes of the slow progress of Iranian localities, which in return has not been able to offer proper educational/hygiene/administrative services to Afghans and the natives. No intention of longterm support provision is also problematic.

There is an urgent need for action on behalf of the Afghans themselves; they are the body they need for the betterment of their life situation in Iran. Contrary to the passive traditional role they have been playing to manage their integration in Iran, the solution to their challenge of being cast away was a more harmonized participation in the modernized life in Iran. Considering the downward movement of economic growth in Iran which led to less and less job opportunities for the Iranian youth, the multiplication of an excess community could be nothing other than more trouble. Also, the traditional outlook toward occupation which held the Afghan workforce in low-paid manual professions has contributed to a more difficult and less probable welcome on behalf of the host society. Therefore, intentions of seeking higher qualification and education by the first wave of Afghans along with more modern knowledge of the family institution could help avoid unhospitable policies regulated against this community. Perhaps the overlapping of the two cultures and language has made integration easier and voluntary return more difficult. Easier integration although a positive phenomenon has become troublesome by creating the gap for some of these people on the verge of returning to their original identity, leading to an unsolvable identity crisis. This study has tried to bring about the significance of more individually focused attention along with policymaking in terms of refugee/asylum seeker people through insistence upon local authorization over decision making for each nation/culture.

\section{Recommendation}

My overall suggestion is that the funding continues again in Iran or any other country that these people reside to raise knowledgeable people who can both work in the host and their country of origin upon return. Also, budgets should be spent on creating real permanent safety in the origin country to guarantee safe life for those interested in repatriation as well as creating an incentive for return in others. Forcing people back to insecure life is non-humanistic and a source of escape, lying, homelessness, abuse of subsidies, etc. If capital investment in the first place is simultaneously allocated to security and local/abroad training/education, after some time, the educated force from abroad willingly returns to a prepared bed for reconstruction. There will be no need for early forceful repatriation that leads to illegal scattering of asylum seekers which consequently requires more capital in form of handling the identification schemes, foreign organization help, and most importantly a host country economy sacrifice.

Most importantly, expert AR is needed by pedagogic anthropologists for coming to a guaranteed framework for designing preparatory school textbooks concentrated on migration wisdom and integration skills based on respecting individual will. 
Graph 1 (Source: Google Maps (bttps://www.google.com/maps/@,32.839153,55.1046807,5.17z) and author)

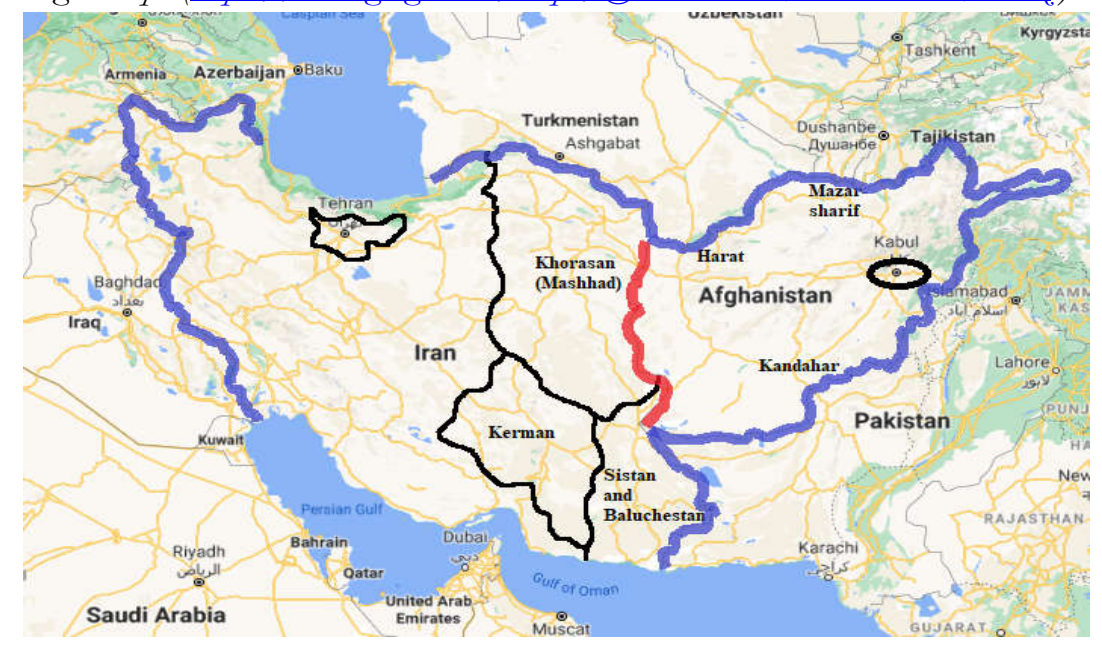

\section{References}

Abbasi-Shavazi, M.J., Glazebrook, D., Jamshidiha, G., Mahmoudian, H., Sadeghi, R. (2008): Second-generation Afghans in Iran: Integration, Identity and Return. Tehran: Afghanistan Research and Evaluation Unit

Azizi, S., Hosseini, S.B., Basavaraju, C. (2017): Evaluating Performance of Iran's Domestic Laws on Effective Protection of Refugees. Journal of International Academic Research for Multidisciplinary, 5. 70-89

European Commission (2021): Facts and Figures: European Civil Protection and Humanitarian Aid Operations

Gordon, M.M., (1964): The Nature of Assimilation. Assimilation in American Life: the Role of Race, Religion, and National Origins. pp. 60-83. New York: Oxford University Press.

Hatch Dupree, N., (2002): Cultural heritage and national identity in Afghanistan. Third World Quarterly, 23:5. 977-989. doi. $\underline{10.1080 / 0143659022000028549}$

Hugo, G., Abbasi-Shavazi, M.J., Sadeghi, R., (2012): Refugee Movement and Development:
Afghan Refugees in Iran. Migration and Development. 1:2. 261-279

Jamshidiha, G., Anbari, M. (2004): Social Belonging and its Impact on the Return of Afghan Refugees. Social Sciences Letter. 23. 43-68 Jauhiainen, J., Eyvazlu, D., Salavati, B., (2020): Afghans in Iran. Migration patterns and aspirations. Finland: Publications of the Department of Geography and Geology of University of Turku.

https://www.researchgate.net/publication/339 253116

Jawad, N., (1992): Afghanistan: A Nation of Minorities. United Kingdom

Khairi, H., Rahimi. M. E., (2018): Identity Differences of First and Second Generation Afghan Migrants in Iran: a Case Study of Hazara Migrants in the city of Qom in 2017. Islam and Social Studies. 2:22, 131-151

Lumpp, K., Shimozawa, S., Stromberg, P., (2004): Voluntary Repatriation to Afghanistan Key Features. Refugee Survey Quarterly. 23:3, 149-173 Marchand, K., Siegel, M., Kuschminder, K., Majidi, N., Vanore, M., Buil, C., (2014): Afghanistan 
Migration Profile. Afghanistan: International Organization for Migration

Mossalanejad, A., (2009): The Evolution of Social Structure and Geopolitic of Power in Afghanistan. The International Quarterly of Geopolitics. 5:14, 168-197

Naseh, M., Potocky, M., Stuart, P.H., Pezeshk, S., (2018): Repatriation of Afghan Refugees from Iran: A Shelter Profile Study. Journal of International Humanitarian Action.13:3, doi.10.1186/s41018-018-0041-8

Squire, C., (2000): Education of Afghan Refugees in the Islamic Republic of Iran. Tehran: UNESCO

Yahyaei, S., Kia, S.M., (2009): A Study of Cultural Identity and National Identity Image of Iranian and Afghans; Regarding to Afghan Immigrants Attitude toward Iranians". Journal of National Studies. 10, 135-156

Yasna, M., (2019): The Position of Persian Language in Afghanistan. Kavoshnameh in Persian Language and Literature. 20, 181-209

Internet resources

Net1: Bhoyroo. F., (2019). Afghan Children Learn Side by Side with Iranian Peers. UNHCR. Retrieved: 16.01.2021. Web: https://www.unhcr.org/news/stories/2019/12 /5defcb6f4/afghan-children-learn-side-sideiranian-peers.html

Net2: Fars News Agency (2014). Endless Exile: An Exclusive Narrative of Afghan Migrants Participating in eight years of The Holy Defence. Retrieved: 25.01.2021. Web: https://af.farsnews.ir/culture/news/139307190 01439

Net3: Fekrat, H. (2009). A Minimized Kabul in Iran. Jadid Online. Retrieved: 15.01.2021. Web: https://www.jadidonline.com/story/18022009 /frnk/afghans_golshahr
Net4: O'mahony, L. (2003). Feature: Young Afghans in Iran read into the future. UNHCR. Retrieved: $\quad 15.01 .2021$ Web: https://www.unhcr.org/news/latest/2003/1/3 e1d8eca4/feature-young-afghans-iran-readfuture.html

Net5: Rokooie, F. (2008) Education and Leisure Time of Afghan Migrant Families settled in margins: A Case Study of Shahrak-e-Rahahan in Tehran. Anthropology and Culture. Retrieved: 14.01.2021., Web: https://anthropology.ir/article/4154.html

Net6: Shakib, S. (2017). How Can Iran Educate a Million Afghan Refugees?. Deutche Welle. Retrieved 16.01.2021., Web: https://www.dw.com/en/how-can-iraneducate-a-million-afghan-refugees/a-40640770

Net7: UNHCR, (1997): UNHCR CDR Background Paper on Refugees and Asylum Seekers from Afghanistan, Retrieved: 22.02.2021., Web: https://www.refworld.org/docid/3ae6a6440.ht $\mathrm{ml}$

Net8: Villen, M. (2008). Better schooling for Afghan refugee children in Iran. Euroactiv. Retrieved: 15.01.2021., Web: https://www.euractiv.com/section/developme nt-policy/news/better-schooling-for-afghanrefugee-children-in-iran/

Institutions mentioned

Khaneye Koodakane Aftab. http://koodakaneaftab.com/eng/about-us KCIS (Keep Children In School). https://keepchildreninschool.org/about-us/ 